\title{
Combined effects of garlic essential oil and allyl isothiocyanate against Escherichia coli 0157:H7 in vitro and in pork sausage
}

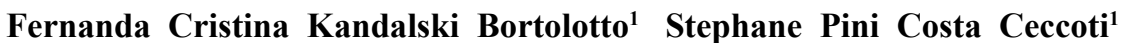 \\ Paloma Bianca Orso ${ }^{1}$ Hanna Lethycia Wolupeck ${ }^{1}$ Richard Alan Holley $^{2}$ \\ Fernando Bittencourt Luciano ${ }^{1}$ Renata Ernlund Freitas de Macedo $^{1^{*}}$ (ै)
}

\footnotetext{
'Programa de Pós-graduação em Ciência Animal, Pontifícia Universidade Católica do Paraná (PUCPR), 80215-901, Curitiba, PR, Brasil. E-mail: renata.macedo@pucpr.br. *Corresponding author.

${ }^{2}$ Department of Food Science, Faculty of Agricultural and Food Sciences, University of Manitoba, Winnipeg, Canada.
}

\begin{abstract}
Escherichia coli O157:H7 is a toxigenic serotype of E. coli and has been associated with foodborne outbreaks involving meat products, vegetables and fresh produces worldwide. Salts for curing are usually employed as antimicrobials in the production of pork sausages. However, salts do not have a significant inhibitory effect on enterobacteria. Due to the growing demand for natural foods, the use of essential oils has been proposed as natural antimicrobials in food. This study aimed to evaluate the effects of garlic essential oil (GO) and allyl isothiocyanate (AITC) against E. coli O157:H7 in vitro and in pork sausage. The Minimal Inhibitory Concentration (MIC) and Minimal Bactericidal Concentration (MBC) of these oils, alone and in combination, against E. coli O157:H7 were determined. Pork sausage was inoculated with 8log CFU/g E. coli O157:H7 and different combinations of GO and AITC. A control group was performed without essential oils. Sausages were packaged and stored at $6^{\circ} \mathrm{C}$ for 20 days. E. coli O157:H7 population and instrumental color $\left(L^{*}, a^{*}, b^{*}, C^{*}\right.$ and hue) determinations were performed at 5-day intervals. AITC showed lower MIC and MBC than GO. When combined, AITC and GO showed a synergistic effect. Treatments T3 and T4 showed 1,01log CFU and 1,87log CFU reduction of E. coli O157:H7 compared to control. The redness and the chroma of sausages treated with AITC and GO increased during storage. Together, GO and AITC caused minor changes in taste and flavor of sausages, and were able to reduce the population of E. coli O157:H7 and to maintain the red color of sausage during storage. Key words: foodborne pathogens, meat products, natural preservatives, synergism.
\end{abstract}

Efeito combinado de óleo essencial de alho e isotiocianato de alila contra Escherichia coli 0157:H7 in vitro e em linguiça suína

RESUMO: Escherichia coli O157:H7 é um sorotipo toxigênico de E. coli associado mundialmente a surtos de doenças alimentares causadas por produtos cárneos. Os sais de cura são normalmente empregados como antimicrobianos na fabricação de linguiças, entretanto, possuem pouco efeito inibitório sobre enterobactérias como E. coli. Devido à crescente demanda por produtos naturais, o uso de óleos essenciais tem sido proposto como antimicrobiano natural em alimentos. O objetivo deste estudo foi avaliar os efeitos do óleo essencial de alho (GO) e isotiocianato de alila (AITC) contra E. coli O157:H7 in vitro e em linguiça. As concentrações inibitória mínima (MIC) e bactericida mínima $(M B C)$ dos óleos, isolados e em combinação, contra E. coli O157:H7 foram determinadas in vitro. Lotes de linguiça foram inoculados com 8log UFC $/ g$ E. coli O157:H7 e diferentes concentrações de GO + AITC e estocados a $6^{\circ} \mathrm{C}$ por 20 dias. Contagens de E. coli O157:H7 e determinação de cor instrumental ( $L^{*}, a^{*}, b^{*}, C^{*}$ e hue) foram realizadas a cada 5 dias. Nos testes in vitro, AITC mostrou maior ação inibitória que $G O$, havendo efeito sinérgico dos óleos quando combinados. Os tratamentos T3 e T4 mostraram redução de 1,01log UFC e 1,87log UFC de E. coli O157:H7 comparados ao controle. A intensidade de cor vermelha e a saturação de cor aumentaram durante a estocagem nas linguiças adicionadas de óleos essenciais. A adição dos óleos GO + AITC causou mínima alteração no sabor e na aparência das linguiças e foi capaz de reduzir a população de E. coli O157:H7 no produto cárneo, mostrando potencial para uso como conservante natural nesse tipo de alimento.

Palavras-chave: conservantes naturais, patógenos, produtos cárneos, sinergismo.

\section{INTRODUCTION}

Different types of fresh pork sausage are very popular in Brazil, comprising $40 \%$ of the meat products produced in this country. The "thin sausage" is a type of sausage very popular in the South of Brazil, made with pork leg, with or without beef meat, curing salts (sodium nitrate and nitrite), condiments, such as black pepper, red pepper, oregano, garlic and onion, stuffed into sheep casing and stored under refrigeration $\left(\leq 6^{\circ} \mathrm{C}\right)$.

Due to its high water activity and the absence of thermal treatment during processing, 
this type of sausage is susceptible to microbial spoilage and usually has short shelf life. Additionally, foodborne diseases may occur when the product is consumed undercooked (SILVEIRA et al., 2014).

Escherichia coli are among the main microorganisms that cause diseases because toxigenic serotypes including E. coli O157:H7 are widely distributed, highly virulent and have low infective doses. This pathogen has been associated with foodborne outbreaks involving meat products worldwide. Although, serotypes of $E$. coli $\mathrm{O} 157: \mathrm{H} 7$ are most often found in beef, these pathogens have also been reported in fresh pork sausages (NORMANNO et al., 2004).

Curing salts (nitrate and nitrite) are employed as antimicrobials in sausages to ensure the safety of the products. However, these salts are mainly effective in inhibiting the growth of Clostridium botulinum and do not have a significant inhibitory effect on many pathogens, including $E$. coli $\mathrm{O} 157: \mathrm{H} 7$, and spoilage microorganisms such as lactic acid bacteria (SEBRANEK; BACUS, 2007). Moreover, there is a growing demand for food with lower levels of synthetic additives (TAJKARIMI et al., 2010). Thus, in fresh sausage the addition of natural compounds with antimicrobial activity might be a strategy to increase both the safety and shelf life of this product (MANTHENJWA et al., 2012).

Among these natural compounds, plant essential oils have been studied as potential natural preservatives for foods (GYAWALI \& IBRAHIM, 2014; MANTHENJWA et al., 2012; LEMAY et al., 2012; CORDEIRO et al., 2013). However, due to their aromatic properties, these oils can influence the flavor and taste of products when added. Alternatively, the use of essential oils from spices that are traditionally used in the formulation of sausage can minimize such adverse effects (TAJKARIMI et al., 2010). In Brazil, garlic and mustard are traditionally used as condiments in the formulation of fresh sausages. The use of garlic oil (GO) as antimicrobial agent in meat products has been reported in fresh sausage (KANDEM et al., 2007) and chicken sausage (SALLAM et al., 2004). Allyl isothiocyanate (AITC), the main isothiocyanate in brown/black mustard essential oil, has also been studied as antimicrobial agent in meat products such as fermented sausages (LUCIANO et al., 2011) and chopped beef (CHACON et al., 2006). However, there is no references on the effects of the combined used of these compounds in fresh sausage. Therefore, the objective of this study was to evaluate the effects of GO and/or AITC in vitro and in sausage inoculated with $E$. coli $\mathrm{O} 157: \mathrm{H} 7$.

\section{MATERIALS AND METHODS}

\section{Materials and inoculum preparation \\ Allyl isothiocyanate (AITC) (Sigma} Aldrich Chemical Co., St. Louis, MO, USA), and garlic oil (GO) (55.2\% allicin) (Sigma Chemical Co. Zhengzhou, Henan, China) were used. A 5-strain mixture of E. coli O157:H7 (E. coli O157:H7 020627, 02-0628, 00-0381, 02-0304, and E. coli O157:H7 NM 02-1840), from the culture collection of the Department of Food Science of the University of Manitoba, Canada, was used in this study. Each bacterial strain was transferred into fresh tryptone soya broth (TSB) (Himedia, Mumbai, India) and allowed to grow overnight $(16 \mathrm{~h})$ at $37^{\circ} \mathrm{C}$. Then, $50 \mu \mathrm{L}$ of each strain was added together to a single tube containing $9.75 \mathrm{ml} \mathrm{TSB}$ broth and cultured for another $16 \mathrm{~h}$ at $37^{\circ} \mathrm{C}$ prior to the experiments. Organisms were cultured again and $0.1 \mathrm{~mL}$ samples at mid-exponential phase were used (optical density $\sim 0.6$, at $600 \mathrm{~nm}$ represented approximately $7 \log \mathrm{CFU} / \mathrm{ml}$ ).

\section{Minimal inhibitory concentration (MIC) and Minimal bactericidal concentration \\ The minimum inhibitory (MIC) and} minimum bactericidal concentration (MBC) of AITC were determined by the broth dilution technique (CLSI, 2009). Screw-capped tubes containing the inoculum, TSB adjusted to $\mathrm{pH} 6.0$, and AITC at 50ppm, 100ppm, 200ppm, or $400 \mathrm{ppm}$ were incubated at $37^{\circ} \mathrm{C}$ for $72 \mathrm{~h}$. The lowest concentration of AITC where there was no visible microbial growth (turbidity) after $24 \mathrm{~h}$ incubation was determined as the MIC, while the MBC was considered the lowest concentration of AITC where there was no visible microbial growth after $72 \mathrm{~h}$.

The MIC and the MBC for GO were determined by standard plate count because the broth became turbid upon addition of this oil due to the formation of an emulsion. Tubes containing TSB adjusted to $\mathrm{pH} 6.0$, the inoculum, and 50ppm, 100ppm, $150 \mathrm{ppm}, 200 \mathrm{ppm}, 400 \mathrm{ppm}$, and $800 \mathrm{ppm}$ of GO were incubated at $37^{\circ} \mathrm{C}$ for $24 \mathrm{~h}$. After incubation, cultures were subjected to serial dilution, plated on plate count agar (PCA, Neogen Corp., Lansing, MI, USA), and incubated at $37^{\circ} \mathrm{C}$ for $24 \mathrm{~h}$. The lowest level of GO that showed a reduction of at least $1 \log \mathrm{CFU} / \mathrm{mL}$ compared to the control (without GO) was considered the MIC. The lowest level of GO that showed a reduction $\geq 3 \log$ $\mathrm{CFU} / \mathrm{mL}$ compared to the control was deemed the MBC (COSENTINO et al., 1999). All determinations were performed in duplicates and the experiment was repeated twice $(n=4)$. 
The MIC of the AITC + GO combination was determined as described in section 2.2. The oils were combined using the following levels: $1 / 2 \mathrm{MIC}$ AITC + 1/8 MIC GO; 1/4 MIC AITC + 1/16 MIC GO; and 1/8 MIC AITC + 1/32 MIC GO. Levels of GO used in tests were reduced from the MIC proportionately greater than that for AITC because of the intense aroma of $\mathrm{GO}$, which might prevent its use as a food additive. Tubes were incubated at $37^{\circ} \mathrm{C}$ for $24 \mathrm{~h}$, and the MIC was determined by the lack of visible microbial growth (turbidity).

The type of the interaction between GO + AITC against E. coli O157:H7 was evaluated by calculating the Fractional Inhibitory Concentration (FIC) Index (GUTIERREZ et al., 2008). FIC index = $\mathrm{FIC}_{\mathrm{GO}}+\mathrm{FIC}_{\mathrm{AITC}}$, where:

$F_{G O}=M C_{G O}$ in combination $M I C_{G o}$ alone $F I C_{\text {AITC }}=M I C_{\text {AITC }}$ in combination $M I C_{\text {AITC }}$ alone

An FIC index $\leq 0.5$ indicated a synergic effect; $0.5<$ FIC index $\leq 1$ represented an additive effect; $1<$ FIC index $\leq 4$ had no interactive effect; and FIC index $>4$ indicated an antagonistic effect.

\section{Preparation of pork sausages}

The AITC + GO combination was tested as antimicrobial in pork sausage, where the lowest level used was 10-fold higher than the MIC determined for these oils in combination. Different combinations of oil treatments were tested: $\mathrm{T} 1=125 \mathrm{ppm} \mathrm{GO}+$ $125 \mathrm{ppm}$ AITC, T2 $=250 \mathrm{ppm}$ GO $+125 \mathrm{ppm}$ AITC, $\mathrm{T} 3=125 \mathrm{ppm}$ GO $+250 \mathrm{ppm}$ AITC, T4 $=250 \mathrm{ppm}$ $\mathrm{GO}+250 \mathrm{ppm}$ AITC. Four batches of pork sausages and a control batch (C), without essential oils, were produced according to a commercial formulation. The study was performed in two replicates and each experimental treatment was composed of two replicates $(n=6)$.

Trimmings from the pork leg (gluteus medius, semimembranosus, semitendinosus and biceps femoris) were ground using an electric grinder (Metalurgica Siemsen, Brusque, Brazil) with an $8 \mathrm{~mm}$ diameter. Dry ingredients $(\mathrm{NaCl}$, sodium phosphate, sodium erythorbate, black pepper, red pepper, oregano, garlic and onion powder, monosodium glutamate and $\mathrm{NaNO}_{2}$ ) (BRC Ingredients, Rio Claro, Brazil) were added to the raw meat and mixed manually for $2 \mathrm{~min}$. Subsequently, the bacterial inoculum was added to the mixture at a final concentration of $6 \log \mathrm{CFU} / \mathrm{g}$ and mixed by hand for $2 \mathrm{~min}$. Finally, GO and AITC were added at the concentrations described previously. After manually mixing for $2 \mathrm{~min}$, approx. $100 \mathrm{~g}$ were embedded in an ovine natural casing (Tripovino,
Araraquara, Brazil), placed in sterile stomacher bags (570671, Laborclin, Pinhais, Brazil) and stored at $6^{\circ} \mathrm{C}$ for $20 \mathrm{~d}$. At $5 \mathrm{~d}$ intervals, samples were drawn to determine the population of E. coli $\mathrm{O} 157: \mathrm{H} 7$ and instrumental color parameters.

\section{Microbiological analysis}

A $25 \mathrm{~g}$ sample, aseptically collected from different points of the sausage, was placed into a sterile bag along with $225 \mathrm{~mL}$ of $0.1 \%$ peptone water. The samples were homogenized $1 \mathrm{~min}$ using a stomacher (IUL Instruments, Barcelona, Spain). Serial dilutions were prepared and samples were plated in Sorbitol McConkey Agar (Himedia, Mumbai, India) with incubation at $37^{\circ} \mathrm{C}$ for $24 \mathrm{~h}$. Light pink colored colonies were identified as E. coli $\mathrm{O} 157: \mathrm{H} 7$.

\section{Instrumental color determination}

The sausage color was measured using a colorimeter (Konica Minolta, Tokyo, Japan), with a D65 illuminant, an opening diameter of $50-53 \mathrm{~mm}$, an observation angle of $2^{\circ}$, and the coordinates $\mathrm{L}^{*}$ (lightness), $\mathrm{a}^{*}$ (red color), $\mathrm{b}^{*}$ (yellow color), $\mathrm{C}^{*}$ (color saturation), and hue angle (discoloration) were recorded.

\section{Preliminary sensory evaluation}

A preliminary sensory evaluation was performed to detect changes in taste and flavor of pork sausage with AITC and GO. Four batches of pork sausage $(100 \mathrm{~g})$ were prepared with the addition of different combinations of AITC and GO as described previously, without inoculation of $E$. coli O157:H7. Sausages were cooked in an electric grill (Oster, model 4777-33, Chicago, IL, USA) until $71^{\circ} \mathrm{C}$ at the internal point. Then, sausages were portioned into cubes $\left(1 \mathrm{~cm}^{3}\right)$ and presented to a five-member trained panel composed of the staff of the Laboratory of Agri-Food Technology.

\section{Statistical analysis}

Results were analyzed by ANOVA and the means were compared using Tukey's test $(P<0.05)$ with the program Statgraphics Centurion XVI v. 16.1.11 (Statpoint Technologies, Warrenton, VA, USA).

\section{RESULTS AND DISCUSSION}

AITC exhibited lower inhibitory (MIC $=50 \mathrm{ppm})$ and bactericidal concentrations $(\mathrm{MBC}=$ 200ppm) against $E$. coli $\mathrm{O} 157: \mathrm{H} 7$ growth than GO $(\mathrm{MIC}=200 \mathrm{ppm}$ and $\mathrm{MBC}>800 \mathrm{pmm})$. Levels of GO greater than $800 \mathrm{ppm}$ were not tested against $E$. coli $\mathrm{O} 157: \mathrm{H} 7$ in vitro because they were considered too 
high for possible use as a preservative food. Usually, the concentration of essential oils has to be increased by $\geq 10$ times in foods to obtain the same results as observed in vitro (BURT, 2004).

LUCIANO and HOLLEY (2009) found the MIC of AITC against E. coli $\mathrm{O} 157: \mathrm{H} 7: \mathrm{H} 7$ in vitro to be $50 \mathrm{ppm}$ at $\mathrm{pH} 6.5$. These authors also reported that the antimicrobial effect of AITC was influenced by the medium $\mathrm{pH}$, and at $\mathrm{pH} 5$ the MIC was lowered to $25 \mathrm{ppm}$. In the present study, the MIC of AITC for $E$ coli $\mathrm{O} 157: \mathrm{H} 7$ in vitro at $\mathrm{pH} 6.0$ was similar to thatreported by LUCIANO and HOLLEY (2009).

NEDOROSTOVA et al. (2009) obtained an in vitro $\mathrm{MIC}$ for $\mathrm{GO}$ against Gram-negative bacteria (E. coli, Salmonella Enteritidis) of $250-$ $550 \mathrm{ppm}$. Gram-positive bacteria were less resistant to GO, with MIC values from 80 to $100 \mathrm{ppm}$. The authors also noted that essential oils containing sulfur compounds, such as AITC and allicin, exhibit the greatest antimicrobial activity among this class of extracts, followed by essential oils containing thymol or carvacrol.

When combinations of AITC and GO were tested in vitro, reduction in the MIC's of the essential oils were noted and they exhibited a synergistic effect (FICindex $<0.5$ ) against $E$. coli O157:H7 at concentrations of $12.5 \mathrm{ppm}$ AITC + $12.5 \mathrm{ppm}$ GO (Table 1). This effect can allow the use of lower concentrations of each essential oil, resulting in a lower impact on the sensory attributes of treated food, while the antimicrobial effect is maintained (SILVA et al., 2009).

An hypothesis for synergy among different essential oils against $E$. coli was proposed by PEI et al. (2009). They proposed that as hydrophobic molecules, many essential oils can cause disturbances in the outer membrane of Gram-negative bacteria, releasing lipopolysaccharides and increasing the permeability of the cytoplasmic membrane, which may allow another essential oil, if present, access to the cytoplasm and enable it to combine with proteins and enzymes, deactivating them. Thus, the synergistic effect is established. Similarly, HYLDEGAARD et al. (2012) stated that essential oils containing different antimicrobial compounds act indirectly at different sites in a bacterial cell, depending on each other to exert their combined antimicrobial action. This suggested that combinations of antimicrobials with different mechanisms of growth inhibition would work best to reduce the necessary levels of preservatives needed to achieve control.

The addition of AITC $+\mathrm{GO}$ in pork sausage was effective in reducing the population of E. coli $\mathrm{O} 157: \mathrm{H} 7$, especially at the highest level used (20-fold higher than the in vitro MIC) (Table 2).

E. coli $\mathrm{O} 157: \mathrm{H} 7$ numbers in $\mathrm{T} 3$ and $\mathrm{T} 4$ were lower $(P<0.05)$ than the control during storage, reaching reductions of 1.01 and $1.87 \log \mathrm{CFU} / \mathrm{g}$ after $20 \mathrm{~d}$, respectively. Similarly, CORDEIRO et al. (2013) reported a reduction of about $2 \log \mathrm{CFU} / \mathrm{g}$ in E. coli $\mathrm{O} 157: \mathrm{H} 7$ numbers of tainted fermented sausages treated with different concentrations of brown mustard powder. Moreover, LEMAY et al. (2002) observed a decrease of $2 \log \mathrm{CFU} / \mathrm{g}$ in E. coli numbers on chilled chicken meat containing 1,000 ppm of mustard essential oil ( $\geq 95 \%$ AITC).

With regards to the instrumental color, there were no significant differences in $\mathrm{L}^{*}$ (lightness) and $\mathrm{b}^{*}$ (yellow color) values among treatments. However, $\mathrm{a}^{*}$ (red color) and $\mathrm{C}^{*}$ (color saturation) values increased during storage in sausage batter to which essential oils were added. Treatments T3 $(125 \mathrm{ppm} \mathrm{GO}+250 \mathrm{ppm}$ AITC) and T4 (250ppm GO $+250 \mathrm{ppm}$ AITC), which received the highest levels of essential oils, showed the highest $\mathrm{a}^{*}$ and $\mathrm{C}^{*}$ values and the lowest hue values during storage $(P<0.05)$. Conversely, control sausages maintained their $\mathrm{a}^{*}, \mathrm{C}^{*}$ and hue values during storage.

Table 1 - Effect of the combination of different concentrations of allyl isothiocyanate (AITC) and garlic essential oil (GO) against E. coli O157:H7 growth in vitro.

\begin{tabular}{lccc}
\hline Combinations of EO & EO levels $(\mathrm{ppm})$ & FICindex & Effect \\
& AITC + GO & & 0.615 \\
$1 / 2 \mathrm{MIC}$ AITC $+{ }_{1 / 8}$ MIC GO & $25+25$ & 0.312 & Additive \\
$1 / 4$ MIC AITC $+{ }_{1 / 16}$ MIC GO & $12.5+12.5$ & - & Synergistic \\
$1 / 8$ MIC AITC $+{ }_{1 / 32}$ MIC GO & $6.25+6.25$ & No effect \\
\hline
\end{tabular}

Tests were incubated at $37^{\circ} \mathrm{C}$ for $24 \mathrm{~h}$. EO = essential oil. FICindex $\leq 0.5$ indicated a synergic effect; $0.5<$ FIC index $\leq 1$ represented an additive effect; $1<$ FICindex $\leq 4$ had no interactive effect; and FIC index $>4$ indicated an antagonistic effect. 
Table 2 - E. coli $\mathrm{O} 157: \mathrm{H} 7$ population (log CFU/g) in pork sausage containing different levels of garlic oil (GO) and allyl isothiocyanate (AITC) $($ mean $\pm \mathrm{sd})$ at $6^{\circ} \mathrm{C}$ storage.

\begin{tabular}{|c|c|c|c|c|c|}
\hline \multirow[t]{2}{*}{ Time (days) } & . & - & -Treatments & ------------ & - \\
\hline & $\mathrm{C}$ & $\mathrm{T} 1$ & $\mathrm{~T} 2$ & $\mathrm{~T} 3$ & $\mathrm{~T} 4$ \\
\hline 0 & $6.57 \pm 0.15^{\mathrm{a}}$ & $6.57 \pm 0.15^{\mathrm{a}}$ & $6.57 \pm 0.15^{\mathrm{a}}$ & $6.57 \pm 0.15^{\mathrm{a}}$ & $6.57 \pm 0.15^{\mathrm{a}}$ \\
\hline 5 & $5.91 \pm 0.08^{c}$ & $6.24 \pm 0.14^{b}$ & $6.69 \pm 0.09^{\mathrm{a}}$ & $5.89 \pm 0.07^{\text {bc }}$ & $5.68 \pm 0.15^{\mathrm{d}}$ \\
\hline 10 & $6.36 \pm 0.05^{\mathrm{a}}$ & $6.25 \pm 0.30^{\mathrm{a}}$ & $5.73 \pm 0.08^{\mathrm{bc}}$ & $5.74 \pm 0.26^{\mathrm{b}}$ & $5.22 \pm 0.14^{\mathrm{c}}$ \\
\hline 15 & $5.92 \pm 0.02^{\mathrm{abc}}$ & $6.27 \pm 0.30^{\mathrm{a}}$ & $6.01 \pm 0.21^{\mathrm{ab}}$ & $5.42 \pm 0.27^{\mathrm{bc}}$ & $5.32 \pm 0.36^{\mathrm{c}}$ \\
\hline 20 & $6.27 \pm 0.13^{\mathrm{a}}$ & $6.16 \pm 0.04^{\mathrm{ab}}$ & $5.86 \pm 0.32^{\mathrm{ab}}$ & $5.56 \pm 0.45^{\mathrm{b}}$ & $4.70 \pm 0.17^{\mathrm{c}}$ \\
\hline $\mathrm{R}$ & 0.30 & 0.41 & 0.71 & 1.01 & 1.87 \\
\hline
\end{tabular}

$\mathrm{C}=$ Control; $\mathrm{T} 1=125 \mathrm{ppm} \mathrm{GO}+125 \mathrm{ppm}$ AITC, T2 $=250 \mathrm{ppm} \mathrm{GO}+125 \mathrm{ppm}$ AITC, T3 = 125ppm GO + 250ppm AITC, T4 = 250ppm GO $+250 \mathrm{ppm}$ AITC. Different letters in the same row indicate significant differences among treatments $(P<0.05)$. R $=$ Reduction of the initial count after $20 \mathrm{~d}(\log \mathrm{CFU} / \mathrm{g})$.

The increased red color of the treated sausages could be associated with an antioxidant effect of these essential oils, which might delay the formation of metmyoglobin and the consequent discoloration of meat. The antioxidant activity of essential oils is mainly attributed to its ability to scavenge free radicals, and inhibit hydrolytic and oxidative enzymes, preserving the color of the treated products (TAJKARIMI et al., 2010). However, in this experiment no antioxidant levels were quantified.

With regards to the preliminary sensory assessment, all combinations of GO and AITC caused minimal changes in taste and flavor of pork sausages and were well accepted by the panelists, showing potential to be used in pork sausage as preservatives.

\section{CONCLUSION}

Concentrations of $125 \mathrm{ppm} \mathrm{GO}+250 \mathrm{ppm}$ AITC and 250ppm GO + 250ppm AITC were able to reduce the population of $E$. coli $\mathrm{O} 157: \mathrm{H} 7$ in pork sausage and caused minimal effect on the taste and flavor of the meat product. These concentrations had no effect on the color of sausages throughout $20 \mathrm{~d}$ of storage at $6^{\circ} \mathrm{C}$. Further studies on the sensory impact and on spoilage microorganisms of pork sausage should be undertaken. Additionally, microencapsulation of essential oils can also be used as a technique to reduce their sensory impact on the fresh sausage.

\section{DECLARATION OF CONFLICTING INTERESTS}

The authors declared no potential conflicts of interest with respect to the research, authorship, and/or publication of this article.

\section{AUTHORS' CONTRIBUTIONS}

FB, FL and RM conceived and designed experiments. $\mathrm{FB}, \mathrm{SC}, \mathrm{PO}$ and $\mathrm{HW}$ performed the experiments and carried out the lab analyses. FB and RM performed statistical analyses of experimental data. FB, RM and $\mathrm{RH}$ prepared the draft of the manuscript.

\section{REFERENCES}

BURT, S. Essential oils: their antimicrobial properties and potential applications in foods - a review. International Journal of Food Microbiology, v.94, p.223-253, 2004. Available from: <http:// jonnsaromatherapy.com/pdf/Burt_Essential_Oils_A_Review_2004. pdf $>$. Accessed: Feb. 22, 2011. doi: 10.1016/j.ij.foodmicro.2004.03.022.

CHACON, P. A., et al. Inhibitory effects of microencapsulated allyl isothiocyanate (AIT) against Escherichia coli O157:H7:H7 in refrigerated, nitrogen packed, finely chopped beef. International Journal of Food Microbiology, v.107, p.231-237, 2006. Available from: <https://www.sciencedirect.com/science/ article/pii/S0168160505004939>. Accessed: Jun. 14, 2013. doi: 10.1016/j.ijfoodmicro.2005.08.030.

Clinical and Laboratory Standards Institute. Methods for dilution antimicrobial susceptibility tests for bacteria that grow aerobically. M7-A8 CLSI, Wayne, PA, 2009. Available from: $<$ https://www.researchgate.net/file.PostFileLoader.html?id $>$. Accessed: Mar. 30, 2011. doi: 610.688.0700www.clsi.org.

COSENTINO, S., et al. In vitro antimicrobial activity and chemical composition of Sardinian Thymus essential oils. Letters in Applied Microbiology, v.29, p.130- 135, 1999. Available from: <http://onlinelibrary.wiley.com/doi/10.1046/ j.1472-765X.1999.00605.x/full>. Accessed: Jan. 25, 2011. doi: 10.1046/j.1472-765X.1999.00605.x.

CORDEIRO, R. P.; et al. Evaluation of deodorized yellow mustard concentrations for control of E. coli $\mathrm{O} 157: \mathrm{H} 7: \mathrm{H} 7$ viability in dry fermented sausage. Food Control, v.33, p.20-24, 2013. Available from: <https://www.sciencedirect.com/science/ article/pii/S0956713513000728 >. Accessed: Mar. 10, 2014. doi: 10.1016/j.foodcont.2013.01.049. 
GUTIERREZ, J., et al. The antimicrobial efficacy of plant essential oil combinations and interactions with food ingredients. International Journal of Food Microbiology, v.124, p.91-97, 2008. Available from: <https://www.sciencedirect.com/science/ article/pii/S0168160508001177>. Accessed: Apr. 13, 2012. doi: 10.1016/j.ijfoodmicro.2008.02.028

GYAWALI, R., IBRAHIM, S.A. Natural products as antimicrobia agents. Food Control, v.46, p.412-429, 2014. Available from: $<$ https://www.sciencedirect.com/science/article/pii/ S095671351400320X>. Accessed: May 30, 2018. doi: 10.1016/j. foodcont.2014.05.047.

HYLDEGAARD, M., et al. Essential oils in food preservation: mode of action, synergies and interactions with food matrix components. Frontiers in Microbiology, v.3, p.1-24, 2012. Available from: <https://www.frontiersin.org/articles/10.3389/ fmicb.2012.00012/full>. Accessed: Jun. 13, 2013. doi: 10.3389/ fmicb2012.00012.

KANDEM, S.S., et al. Shelf-life and safety characteristics of Italian Toscana traditional fresh sausage (Salsiccia) combining two commercial ready-to-use additives and spices. Food Control, v.18, p.421-429, 2007. Available from: <https://www.sciencedirect. com/science/article/pii/S0956713505002884>. Accessed: Dec. 10, 2012. doi: 10.1016/j.foodcont.2005.11.013.

LEMAY, M. J., et al. Antimicrobial effect of natural preservatives in a cooked and acidified chicken meat model. International Journal of Food Microbiology, v.78, p.217-226, 2012. Available from: <https://www.sciencedirect.com/science/article/pii/ S0168160502000144>. Accessed: Jan. 15, 2013. doi: 10.1016/ S0168-1605(02)00014-4.

LUCIANO, F. B.; HOLLEY, R. A. Enzymatic inhibition by allyl isothiocyanate and factors affecting its antimicrobial action against E. coli O157:H7:H7. International Journal of Food Microbiology, v.131, p.240-245, 2009. Available from: $<$ https://www.sciencedirect. com/science/article/pii/S016816050900155X>. Accessed: Nov. 20, 2013. doi: 10.1016/j.ifoodmicro.2009.03.005.

LUCIANO, F. B., et al. Microbial and chemical origins of the bactericidal activity of thermally treated yellow mustard powder toward Escherichia coli $\mathrm{O} 157: \mathrm{H} 7: \mathrm{H} 7$ during dry sausage ripening. International Journal of Food Microbiology, v.145, p.69-74, 2011. Available from: $<$ https://www.sciencedirect.com/science/ article/pii/S0168160510006586>. Accessed: Nov. 20, 2013. doi: 10.1016/j.ifoodmicro.2010.11.028.

MANTHENJWA, S. A., et al. Effect of alternative preservatives on the microbial quality, lipid stability and sensory evaluation of boerewors. Meat Science, v.91, p.165-172, 2012. Available from: <https://
www.sciencedirect.com/science/article/pii/S0309174012000150>. Accessed: Mar. 07, 2014. doi: 10.1016/j.meatsci.2012.01.014.

NEDOROSTOVA, L., et al. Antimicrobial properties of selected essential oils in vapour phase against foodborne bacteria. Food Control, v.20, p.157-160, 2009. Available from: <https://www. sciencedirect.com/science/article/pii/S0956713508000960>. Accessed: Sept. 20, 2012. doi: 10.1016/j.foodcont.2008.03.007.

NORMANNO, G., et al. Typing of E. coli O157:H7 strains from fresh sausage. Food Microbiology, v.21, p.79-82, 2004. Available from: <https://www.sciencedirect.com/science/article/ pii/S0740002003000194>. Accessed: Sept. 20, 2012. doi: 10.1016/ S0740-0020(03)00019-4.

PEI, R-S., et al. Evaluation of combined antibacterial effects of eugenol, cinnamaldehyde, thymol, and carvacrol against $E$. coli with an improved method. Journal of Food Science, v.74, p.379-383, 2009. Available from: <http://onlinelibrary.wiley.com/ doi/10.1111/j.1750-3841.2009.01287.x/full>. Accessed: Jun. 15, 2013. doi: 10.1111/j.1750-3841.2009.01287.x.

SALLAM, K.I., et al. Antioxidant and antimicrobial effects of garlic in chicken sausage. Lebensmittel-Wissenschaf und Technology, v.37, p.849-855, 2004. Available from: <https:// www.sciencedirect.com/science/article/pii/S0023643804000891>. Accessed: Feb. 24, 2014. doi: 10.1016/j.lwt.2004.04.001.

SEBRANEK, J. G.; BACUS, J. N. Cured meat products without direct addition of nitrate or nitrite: what are the issues? Meat Science, v.77, p.136-147, 2007. Available from: <https://www. sciencedirect.com/science/article/pii/S0309174007001209>. Accessed: Jul. 17, 2011. doi: 10.1016/j.meatsci.2007.03.025.

SILVA, M. T. N., et al. Atividade antibacteriana dos óleos essenciais de plantas frente a linhagens de Staphylococcus aureus e Escherichia coli isoladas de casos clínicos humanos. Revista Brasileira de Plantas Medicinais, v.11, p.257-262, 2009. Available from: $<$ https://repositorio.unesp.br/handle/11449/18117>. Accessed: Oct. 18, 2013. doi: 10.1590/51516-0572209000300005.

SILVEIRA, S. M., et al. Chemical composition and antibacterial activity of Laurus nobilis essential oil toward foodborne pathogens and its application in fresh Tuscan sausage stored at $7^{\circ} \mathrm{C}$. LWT - Food Science and Technology, v.59, p.86-93, 2014. Available from: $<$ https:// www.sciencedirect.com/science/article/pii/S0023643814003211>. Accessed: Jun. 30, 2015. doi: 10.1016/j.lwt.2014.2014.05.032.

TAJKARIMI, M., et al. Antimicrobial herb and spice compounds in food. Food Control, v.21, p.1199-1218, 2010. Available from: $<\mathrm{https} / /$ www.sciencedirect.com/science/article/pii/S0956713510000459>. Accessed: May 15, 2014. doi: 10.1016/j.foodcont.2010.02.003. 